\title{
Um mundo de mulheres em Florianópolis: entrevista com Caroline Andrew
}

\author{
Cíntia Lima Crescêncio \\ Universidade Federal de Santa Catarina, Florianópolis, \\ Santa Catarina, Brasil \\ Maurício Pereira Gomes \\ Universidade Federal de Santa Catarina, Florianópolis, \\ Santa Catarina, Brasil
}

\begin{abstract}
Caroline Andrew, cientista política e liderança feminista, professora da Universidade de Ottawa há mais de 30 anos, concedeu essa entrevista durante um intervalo para o almoço no Women's Worlds Congress (WWC), em Hyderabad/Índia, no dia 16 de setembro de 2014. Durante o encontro, de pouco menos de uma hora, falou de feminismo e academia, relatando a experiência canadense na organização do Congresso Mundos de Mulheres, em 201 1, bem como sobre as expectativas para o próximo encontro, que ocorrerá em Florianópolis, em 2017.
\end{abstract}

\section{(c) (7)}

Esta obra está sob licença Creative Commons. 
Maurício Pereira Gomes (MPG): Boa tarde. Você poderia nos falar sobre sua trajetória de vida? Como foi sua experiência acadêmica?

Caroline Andrew (CA): Passei direto do ensino médio para a Universidade, me graduei em Vancouver, fiz mestrado na Universidade Laval, em Quebec City, e meu doutorado em Toronto, sempre na área da ciência política, com uma perspectiva bastante tradicional. A experiência na cidade de Quebec também foi uma oportunidade para dominar a língua francesa.

MPG: Quando e como você se reconheceu como feminista? Essa identificação aconteceu no espaço acadêmico?

CA: Sim, eu sempre fui interessada em estudos de mulheres, mas, em meus primeiros anos na carreira universitária, eu não sabia como poderia ensinar sobre elas que, afinal, estavam invisibilizadas no espaço político e na ciência política. $\mathrm{Na}$ realidade, eu sempre pensei como feminista, ainda que não utilizasse essa denominação, mas não tinha clareza como poderia atuar e lecionar na área. Então, eu levei um tempo para descobrir e entender que há uma série de teorias sobre as ausências e invisibilidades e, quando isso aconteceu, eu me senti mais à vontade para lecionar no campo dos estudos feministas. Em minhas pesquisas, estudei a relação existente entre a atuação de grupos feministas comunitários, organizações feministas e governos municipais, nos quais é marcante a ausência de mulheres.

MPG: Como é a relação entre o movimento feminista e a universidade no Canadá?

CA: Eu acho que o relacionamento de modo geral tem sido distante, mas, ao longo do tempo, foram estabelecidas conexões em algumas questões, enquanto, em outras, há alguma resistência. Há muitos problemas envolvidos e isso depende das pessoas, sendo certo que grupos feministas de base comunitária têm participado de pesquisas encampadas por universidades e, por outro lado, muitas feministas acadêmicas ocupam espaços na militância em movimentos feministas organizados, estabelecendo relações que nem sempre são tranquilas.

MPG: Como foi a articulação entre academia e movimento feminista na concepção e organização do WWC, no Canadá, em 2011 ?

CA: Foi um momento muito feliz porque conhecemos muitas pessoas de universidades canadenses na Conferência da Coréia, onde foi tomada a decisão de que era hora de o Canadá sediar o próximo encontro. As duas diretoras da Conferência, provenientes da universidade, tiveram a sorte de ter o apoio e o trabalho de Lise Martin, que contava com mais de 20 anos de experiência 
no movimento feminista e tinha sido diretora do Centro de Pesquisas do Canadá sobre Movimentos de Mulheres. Lise Martin foi fundamental na organização e na articulação com grupos feministas de base comunitária e universitária, além de grupos aborígenes, com os quais foi estabelecida uma rede de contatos, com o incentivo e apoio para que participassem ativamente da concepção e organização do evento, sendo responsáveis, inclusive, pela escolha de quem falaria por eles. Também tivemos muita sorte em conseguir apoio financeiro de nosso Ministério da Condição da Mulher, mas, não para a Conferência propriamente dita, e, sim, para sua divulgação e promoção. Assim, foi possível realizar oficinas em todo o Canadá com grupos de mulheres de base comunitária, divulgando a Conferência, explicando sua importância e como elas poderiam chegar a Ottawa. Não sem razão, portanto, tivemos uma grande participação de muitos grupos de mulheres de base comunitária, de modo que fomos capazes de estruturar um programa estabelecendo um equilíbrio na participação de ativistas e de pessoas ligadas às universidades.

MPG: Como você acha que a academia pode melhorar a relação com o movimento feminista?

CA: Eu acho que uma das coisas que funcionou bem, conosco, foi o estabelecimento de contatos com grupos de mulheres locais, porque, às vezes, organizações mais amplas e antigas têm um histórico de relacionamento com a universidade que não é bom. Já, para grupos menores e distantes, a possibilidade de participar de uma Conferência em Ottawa era muito estimulante, além de representar uma oportunidade para conhecer pessoas de todo o mundo, para falarem, sendo que e apresentaram suas histórias muito locais, o que, afinal, contribuiu para a comunhão de uma espécie de sentimento de pertencimento, de parceria.

Cíntia Lima Crescêncio (CLC): Quais foram os impactos causados pelo WWC Canadá nas lutas feministas do período? É possível identificar permanências?

CA: É muito interessante pensar sobre os impactos do WWC realizado no Canadá porque, certamente, não é o mesmo impacto que testemunhamos na Coréia, em que a organização envolvia toda a Ásia, mas há pequenas realizações que se tornaram permanentes. São comuns os relatos de mulheres que estiveram no Canadá, para a Conferência, e fizeram uma série de contatos que ainda hoje se mantém e fortalecem uma rede de oficinas, palestras, treinamentos, enfim, trocas com pesquisadoras e militantes que se conheceram através do WWC. Não é possível identificar, de maneira exata, os impactos, porém, os relatos de construção de redes de contato, bem como de reflexões causadas pelas experiências na Conferência, são uma evidência importante. Além disso, no caso do Canadá, um 
resultado relevante foi a melhoria nas relações entre as mulheres aborígenes e as mulheres acadêmicas. Isso aconteceu em função do espaço que elas tiveram para discutir no WWC e, também, da necessidade de decisão em termos de organização, uma vez que todas eram responsáveis por tomar as decisões que fariam a Conferência acontecer. Eu acho que esse trabalho coletivo, em rede, foi, de maneira geral, muito positivo. O mesmo vale para as mulheres com deficiência que se sentiram ouvidas durante a organização e realização da Conferência. Desde então, elas têm fortalecido trabalhos e pesquisas junto à universidade, porque o modelo de organização do WWC permitiu que elas percebessem que tinham muito a oferecer em trabalhos desenvolvidos conjuntamente com mulheres da academia. Nesses dois casos, o impacto é maravilhoso, permanente e possível de ser mapeado.

CLC: Agora é importante falarmos sobre a experiência na Índia. Nessa Conferência de 2014 parece muito presente a discussão sobre violência contra mulher. Nós temos visto muitos painéis e palestras discutindo o assunto. Quais são suas impressões sobre o encontro na Índia? Comparando às discussões que prevaleceram no Canadá, em 201 1, que tendências são possíveis de ser identificadas nos últimos anos?

CA: Não há dúvidas de que o problema da violência contra a mulher ainda é uma grande questão. Talvez esteja ficando ainda maior em função do reconhecimento público que vem recebendo nos últimos anos. O que, muitas vezes, é chamado de "efeito bumerangue", quando um acontecimento internacional pressiona uma reação nacional ou o inverso, quando um acontecimento local provoca uma reação internacional, tem colaborado na visibilização e consequente reconhecimento da violência contra a mulher, doméstica e pública, como um problema de ordem mundial. Esse assunto está sendo muito mais discutido aqui, na Índia, em 2014, do que foi no Canadá, em 2011. Não apenas a discussão é interessante e importante, mas, também, as formas como ela tem sido desenvolvida e o problema combatido demonstram um esforço de resolução da violência contra a mulher como um problema políitico.

MPG: Você poderia falar algumas palavras sobre os estudos LGBT no Congresso?

CA: Sim, eu acho que o que há de novo é uma maior quantidade de discussões sobre isso. Discussões que envolvem aspectos relacionados com a questão do gênero como um todo. Há muito mais pesquisas e estudos e essa maior visibilidade presente nesta conferência é reflexo tanto de um maior interesse acadêmico, como, também, de um ativismo crescente. Acho que isto é um dos pontos fortes desta Conferência, mais pessoas da

584 Estudos Feministas, Florianópolis, 24(2): 581-585, maio-agosto/2016 
comunidade e da academia querem espaço para falar sobre trans, sobre identidades e temáticas LGBT.

CLC: Quais são suas expectativas para o Women's Worlds Congress Brasil, em 2017?

CA: Eu tenho excelentes expectativas. Eu sempre tive vontade de conhecer o Brasil e os relatos que ouço sobre as conferências feministas que vocês organizam com milhares de participantes me animam ainda mais. Há uma grande excitação e expectativa para tomarmos conhecimento das diferentes Américas e, ainda, do português e do espanhol. O Brasil recente tem uma história muito interessante, principalmente por sua entrada no BRICS. É um país enorme, que está crescendo muito economicamente, mas que nós conhecemos muito pouco. Há muito entusiasmo para o WWC Brasil em 2017.

CLC: Quais serão os desafios para a organização do próximo encontro diante do momento vivido pelo movimento feminista no mundo?

CA: Um deles foi aquele que enfrentamos no Canadá: fazer as pessoas chegarem até o local do congresso, no caso, o Brasil. Nós tínhamos um governo terrível, que estava reduzindo todo o tipo de programa destinado às mulheres ou dificultando a colaboração internacional no que se referia à emancipação das mulheres. Haverá desafios em descobrir modos de levar as pessoas ao Brasil em 2017. Meu conselho para a organização é começar cedo a elaborar meios de levantar recursos localmente. Mas eu penso que a presença da comitiva brasileira, aqui na Índia, é um bom começo, e, assim, vocês estão aptas a acessar organizações nacionais e pessoas que já estiveram em conferências anteriores. Outro desafio é organizar as plenárias, decidir as palestrantes, as coordenadorias de mesa. Porém, o desafio principal é tentar garantir que pessoas de países com menos suporte para igualdade de gênero participem do encontro no Brasil. É importante que essas pessoas sejam motivadas desde já a pensar realisticamente como ir ao Brasil participar da Conferência e elaborar meios de levantar recursos.

\section{Errata}

Na entrevista "Um mundo de mulheres em Florianópolis: entrevista com Caroline Andrews", com n de DOI: http://dx.doi.org/10.1590/1805-9584-2016v24n2p581, publicada na Revista Estudos Feministas, volume 24(2): http://www.scielo.br/scielo.php?script=sci_arttext \&pid=S0104-0266X2016000200581\&lng=en\&nrm=iso\&tlng=pt, no título e no parágrafo inicial, na versão HTML, e na página 581, na versão PDF, onde se lia:

Caroline Andrews

Leia-se

Caroline Andrew.

O mesmo erro ocorreu nos sumários em português e inglês. 